\title{
Level of Vitamin D3 in Women Who Have Uterine Fibroids
}

\author{
Original Mai Amr Mohamed Alansary and Abd El Megeed Ismail Abd El Megeed \\ Article \\ Department of Obstetrics and Gynecology, Faculty of Medicine, Ain-Shams University, \\ Cairo, Egypt
}

\begin{abstract}
Background: Uterine fibroid are the most common benign pelvic tumors among women in reproductive age group that has multifactorial pathogenesis. Vitamin D has become one of the key elements of modern theories of uterine fibroid pathogenesis. Aim: This work aim to investigate the association between vitamin D3 status and uterine leiomyoma.

Materials and Methods: This observational case control study was conducted on 150 women in their reproductive age (20-45 years) at Ain-Shams University Hospital in the department of Obstetrics and Gynecology from March 2019 till August 2019. They were divided into two groups. 75 women with at least one uterine fibroid detected by transvaginal ultrasound to be considered as case group and the other 75 women with normal uterine examination and transvaginal ultrasound representing the control group.

Results: In the current study, there was a statistically significant difference between cases group and control group as regard 25(OH) D level $(P=0.001)$, the mean vitamin D level in the case group was $13.39 \pm 7.93 \mathrm{ng} / \mathrm{ml}$ and in the control group was $21.71 \pm 8.95 \mathrm{ng} / \mathrm{ml}$. There was no statistical significant difference between the size of fibroid and vitamin D level. The mean serum vitamin D level in patients with small fibroid (size less than $5 \mathrm{~cm}$ ) was $14.11 \mathrm{ng} / \mathrm{ml}$ and $12.76 \mathrm{ng} / \mathrm{ml}$ for women with large fibroid (size more than $5 \mathrm{~cm})(P=0.457)$.
\end{abstract}

Conclusion: There is a significant association between vitamin D deficiency in reproductive age women and uterine fibroid. There is no correlation between vitamin D level and the size of uterine fibroid.

Key Words: Fibroids, uterine, vitamin D3

Received: 30 August 2019, Accepted: 27 September 2019

Corresponding Author: Mai Amr Alansary, Department of Obstetrics and Gynecology, Faculty of Medicine, Ain-Shams University, Cairo Tel.: 01111878386, E-mail: maialansary2012@gmail.com

ISSN: 2090-7265, May 2021, Vol.11, No. 2

\section{INTRODUCTION}

Uterine fibroids (UFs) are benign tumors arising from the smooth muscle cells of the uterine wall. They constitute one of the most common pathologies of the female genital tract with an estimated incidence of $20-40 \%$ in women during their reproductive years and increasing to reach up to $65 \%$ of women by the age of 50 years ${ }^{[1]}$.

The origin of UFs is multifactorial and that is why there are no specific methods of prevention at present. They are more prevalent among reproductive aged women and are not observed in pre-pubescent girls, indicating that tumor origin depends on hormonal changes. Other risk factors includes: black race, elevated body mass index (BMI), age, premenopausal status, hypertension, positive family history, time elapsed since last labor, consumption of food additives, and soybean milk ${ }^{[2]}$.

Genetic studies have proven UFs to be monoclonal hormone-dependent tumors. Tumor development begins with the creation of a pathologically changed and transformed primary myometrial cell. Subsequently, all secondary cells divide, making the tumor grow further. Modified cells need proper stimulation in order to divide and produce the extracellular matrix ECM. The mechanisms controlling the growth of UFs are complex and still not well recognized. Abnormal and excessive ECM production is a major factor in UF growth ${ }^{[3]}$.

Vitamin D is a fat soluble steroid compound. It is either produced in the skin by the action of ultraviolet B (UVB) in response to direct exposure to sunlight or obtained from the diet and supplementation. Vitamin D has been known for its roles in calcium and phosphate homeostasis and bone health, but during the last 15 years, it has attracted increased attention. This is mainly due to new discoveries about the impact of vitamin D on several health outcomes and the large variation in the prevalence of vitamin D deficiency across countries worldwide, with estimates ranging from 7 to $90 \%{ }^{[4]}$.

Vitamin D exerts its powerful effects on the human body through a specific type of receptor (VDR) which is the mediator of the pleiotrophic effect of this vitamin as it is found in various organs including musculoskeletal, nervous and immune systems, as well as the genital tract including myometrium ${ }^{[5]}$.

Decreased serum vitamin D levels have been already confirmed in several gynecological and obstetrical pathologies, such as infertility or polycystic ovary 
syndrome and irregular menstrual cycles. Recent theories and researches about the vital role of vitamin D in the pathogenesis of uterine fibroids, have gained new momentum. Vitamin D has become one of the key elements of modern theories of uterine fibroid pathogenesis. ${ }^{[6]}$.

Vitamin D takes part in cell cycle regulation, cell differentiation, apoptosis and it also has an anti-angiogenic activities. This vitamin can modulate the expression of various genes in a tissue-specific manner, and then can lead to the inhibition of cell proliferation, differentiation, and apoptosis. These processes can take part in the inhibition of neoplastic transformation as well as tumor growth ${ }^{[7]}$.

\section{AIM OF THE WORK}

The aim of the study is to investigate the association between vitamin $\mathrm{D}$ status and uterine fibroid.

\section{PATIENTS AND METHODS}

The study was designed as an observational case control trial at Ain Shams University Hospital at the department of Obstetrics and Gynecology from March 2019 to August 2019. The study was conducted on 150 women in their reproductive age (20-45 years). They were divided into two groups: 75 women with at least one uterine fibroid with a diameter less than $5 \mathrm{~cm}$ (Small fibroid), equal or more than $5 \mathrm{~cm}$ (Large fibroid) detected by transvaginal ultrasound to be considered as case group and the other 75 women with normal uterine examination and transvaginal ultrasound representing the control group. There was no drop out rate neither in cases nor control groups of the study participants.

Women were excluded from the study recruitment if they were: pregnant, lactating, aborted in the last 6 months, taking vitamin D supplementation or hormonal contraception, having ovarian cyst of any size or nature, adenomyosis or endometriosis, had previous history of myomectomy and having any chronic organ dysfunction or malignancy.

The study was approved by the local institutional ethical committee and an informed oral medical consent was taken from all participants after full explanation of the steps and significance of this study.

All patients in the two groups were subjected to complete history taking including: Personal and demographic data (Age, residence, social status and habits). Degree of sun exposure: By asking women about the number of hours per day of direct sun exposure. Categories were $<1$ hour/ day for low exposure, 1 hour/day for medium exposure and more than 1 hour/day for high sun exposure. Menstrual history (Duration, frequency, regularity, menstrual blood flow and menstrual pain (dysmenorrhea)). Obestatric history and method of contraception. Patient complaint (Asymptomatic, uterine bleeding, Pain, voiding disorder, infertility). Medical, surgical and drug history.
Then physical examination was done for all participants including: General, Body Mass Index (BMI), abdominal, pelvic and vaginal examination. Ultrasound evaluation was performed by transvaginal ultrasound (TVU) for all enrolled subjects, while transabdominal ultrasonography was performed as needed for some subjects for whom TVU was not sufficient to evaluate the fibroid lesions particularly, large fundal fibroids or virgin women. The ultrasonography was performed using Samsung Medison UGEO H60 ultrasound machine - fitted with an EVN 4-9 $\mathrm{MHz}$ endovaginal probe for the transvaginal scan and CA 1-7 MHz convex probe for the abdominal scan. The following parameters were evaluated by TVU: Total uterine size, as measured in three perpendicular planes. Number and size of fibroid lesions (small= less than $5 \mathrm{~cm}$. equal or large $=5 \mathrm{~cm}$ or more), Position/location of each fibroid lesion within the uterus (uterine fundus, lower uterine segment, cervix, extrauterine). Unusual characteristics (echogenicity, presence of calcifications, presence of central necrosis, etc) of each fibroid lesion. Sonographic appearance of leiomyomas was defined as symmetrical, well defined, hypoechoic and heterogenous masses.

All enrolled women in both groups underwent blood sample withdrawal to measure Serum vitamin D level using Electro-chemiluminecence immune Assay (ECLIA) technique. Blood sample was collected by venipuncture and the sample was kept in standard sampling tube without anticoagulants, clotting is allowed. Then, the blood sample was centrifugated at a speed of $4000 \mathrm{rbm}$. This results in separation of the plasma from other blood components. Vitamin D level in plasma was analysed using automated Electrochemilumecenc Immuno Assay ECLIA (Cobas _e immuno-analyser), the used Kit (05894913-190) manufactured by Roche, Germany. The analyzer automatically calculates the analyte concentration of each sample (either in $\mathrm{ng} / \mathrm{mL}$ or $\mathrm{nmol} / \mathrm{L}$ ).

\section{Conversion Factors}

$$
\mathrm{nmol} / \mathrm{L} \text { x } 0.40=\mathrm{ng} / \mathrm{mL} \text {. }
$$

$\mathrm{ng} / \mathrm{mL} \times 2.50=\mathrm{nmol} / \mathrm{L}$.

According to the Endocrine Society Practice Guidelines on vitamin D3 status, "deficiency" is defined as vitamin D3 level of $<20 \mathrm{ng} / \mathrm{mL}$, insufficiency as $21-29 \mathrm{ng} / \mathrm{mL}$, and sufficiency as at least $30 \mathrm{ng} / \mathrm{mL}$ (for the best overall musculoskeletal effect). The preferred range is from 40 to $60 \mathrm{ng} / \mathrm{mL}$ when focusing on the multiple effect of vitamin $\mathrm{D} 3^{[8]}$.

\section{Sample Size Justification}

The required sample size has been calculated using STATA program version 10 , setting alpha error at $5 \%$ and power at $80 \%$. Results from previous study conducted by (Sabry et al., 2013) ${ }^{[14]}$ showed that the mean vitamin D in cases was $24.45+/-12.85$ compared to $29.53+/-8.13$, among controls. Based on this, the needed sample is 75 cases and 75 controls with taking in consideration $5 \%$ drop out rate. 


\section{STATISTICAL ANALYSIS}

Data was analyzed using IBM( $)$ SPSS $\subset$ Statistics version 23 (IBMC) Corp., Armonk, NY). Normally distributed numerical data was presented as mean and $\mathrm{SD}$, and skewed data as median and interquartile range. Qualitative data was presented as number and percentage. Comparison of normally distributed numerical data was done using the unpaired $t$ test. Skewed data was compared using the Mann-Whitney test. Categorical data was compared using the chi-squared test or Fisher's exact test. The confidence interval was set to $95 \%$ and the margin of error accepted was set to 5\%. $P$-value: Level of significance: $P>0.05$ : Non-significant (NS) $P<0.05$ : Significant (S) $P<$ 0.01: Highly significant (HS). Receiver-Operating Characteristic (ROC) curve analysis was used to examine the value of serum vitamin $\mathrm{D}$ level for discrimination between patients with uterine fibroids and control.

\section{RESULTS}

This study was conducted on 150 women in their reproductive age, divided into two groups; Case group, including 75 women with uterine fibroid and Control group Including 75 women with normal uterine examination and transvaginal ultrasound. All study participants are subjected to blood sample withdrawal to measure serum vitamin D level using electrochemiluminecence immune Assay (ECLIA) technique. There was no statistical significant difference between both study groups as regard age, BMI, Social status and smoking habit $(P>0.05)$ (Table 1).

In the current study, there was a statistically significant difference between cases group and control group as regard $25(\mathrm{OH}) \mathrm{D}$ level $(P=0.001)$, the mean vitamin $\mathrm{D}$ in the case group was $13.39 \pm 7.93 \mathrm{ng} / \mathrm{ml}$ and in the control group was $21.71 \pm 8.95 \mathrm{ng} / \mathrm{ml}$. Out of 75 cases 60 women $(80 \%)$ were found having deficient vitamin $\mathrm{D}$ levels while in controls they were 11 women $(14.7 \%)$ with odds ratio (OR of 7.75) thus vitamin D deficient women are 7.75 times more liable to develop uterine fibroid than women having vitamin D sufficient levels. Also, in the present study, 11 women in the case group $(14.7 \%)$ were vitamin D insufficient, while 31 women $(41.3 \%)$ in the control group were insufficient with ( $p$ value 0.001 and odds ratio OR of 1.3). Thus, the risk of having uterine fibroid in vitamin D insufficient women was 1.3 times more than women having sufficient vitamin D level (Table 2).

There was a statistically significant difference between cases and control groups regarding the duration of daily sunlight exposure $(P<0.05)$. Women who are exposed to sunlight less than $1 \mathrm{hr}$ /day are 7.52 more liable to have uterine fibroid and women who are exposed to sunlight equal to $1 \mathrm{hr} /$ day are 3.98 more liable to have uterine fibroid. There was highly statistical significant difference between cases and control groups regarding the duration of daily sunlight exposure $(P<0.05)$ (Table 3$)$.

All women in this study, who were exposed to daily sunlight for less than $1 \mathrm{hr}$, were found to have deficient serum vitamin D level. 37 women were exposed to sunlight equal to $1 \mathrm{hr} /$ day, no one of them had sufficient vitamin D level, 24 women of them had deficient vitamin D level and 13 women had insufficient level. 72 women were exposed to sunlight for more than $1 \mathrm{hr} /$ day, 24 women of them had deficient vitamin D level, 29 women had insufficient level and 19 women had sufficient vitamin D level. All women with sufficient vitamin D level were exposed to sunlight for more than $1 \mathrm{hr} /$ day. There was statistical significant difference between vitamin $\mathrm{D}$ level and sun exposure $(P<0.05)$ (Table 4$)$.

Regarding the secondary outcome for the current study, we investigated the correlation between serum vitamin $\mathrm{D}$ level and the size of uterine fibroid ( $\mathrm{small}=$ less than $5 \mathrm{~cm}$ and large $=$ more than $5 \mathrm{~cm}$ ). The mean serum vitamin $\mathrm{D}$ level in patients with fibroid size less than $5 \mathrm{~cm}$ was $14.11 \mathrm{ng}$, while women with fibroid size more than $5 \mathrm{~cm}$ had mean serum vitamin D level of $12.76 \mathrm{ng} / \mathrm{ml}$ with $(P=0.457)$ with no statistical significant difference between the size of fibroid and vitamin D level. As regard the different locations of uterine fibroid, the interstitial fibroid was the highest in number 50 women $(66.6 \%)$ followed by submucosal fibroid in 15 women (20\%), subserosal fibroid in 9 women $(12 \%)$ and one case of cervical fibroid (1.3\%). As regard the distribution of the studied patients for their presenting symptoms. Abnormal uterine bleeding was the dominant symptom in the cases group. The number of women presenting mainly with bleeding was 57 women $(76 \%)$, pain was reported in 24 women $(32 \%)$ and infertility in 13 women (17.3\%). There was no statistical significant difference between the size of fibroid and vitamin D level and $(P>0.05)$ ( Table 5).

The diagnostic performance of vitamin $\mathrm{D}$ test in diagnosing uterine fibroid through illustrating sensitivity and specificity of vitamin $\mathrm{D}$ level to predict uterine fibroid. Area under the curve was 0.754 with cut off value $<5 \mathrm{ng} / \mathrm{ml}$, the sensitivity of vitamin $\mathrm{D}$ to predict the fibroid was $77.2 \%$, the specificity was 61.2 and test accuracy was $71.6 \%$ ( Figure 1). 
Table 1: Comparison between case and control groups regarding the age, BMI, Social status and smoking habit of participants

\begin{tabular}{|c|c|c|c|c|c|c|c|c|}
\hline & \multicolumn{5}{|c|}{ Group } & \multicolumn{2}{|c|}{ Independent sample $\mathrm{t}$ test } & \multirow[t]{3}{*}{ P-value } \\
\hline & \multicolumn{3}{|c|}{ Case group } & \multicolumn{2}{|c|}{ Control group } & & & \\
\hline & & Mean & $\pm \mathrm{SD}$ & Mean & $\pm \mathrm{SD}$ & & & \\
\hline Age & & 38.50 & 6.56 & 37.01 & 7.11 & 0.581 & & 0.412 \\
\hline BMI & & 26.93 & 4.29 & 26.25 & 4.672 & 0.17 & & 0.355 \\
\hline \multirow[t]{3}{*}{ Variables } & \multicolumn{7}{|c|}{ Group } & \\
\hline & \multicolumn{3}{|c|}{ Case group } & \multicolumn{2}{|c|}{ Control group } & & Chi square & P-value \\
\hline & & No. & $\%$ & No. & $\%$ & & & \\
\hline \multirow{4}{*}{ Social status } & Married & & 68 & $90.7 \%$ & 62 & $82.67 \%$ & \multirow{4}{*}{1.264} & \multirow{4}{*}{0.532} \\
\hline & Divorced & & 2 & $2.7 \%$ & 4 & $5.33 \%$ & & \\
\hline & Virgin & & 5 & $6.66 \%$ & 9 & $12.0 \%$ & & \\
\hline & Total & & 75 & $100.0 \%$ & 75 & $100.0 \%$ & & \\
\hline \multirow{3}{*}{ Smoking } & No & & 72 & $96.0 \%$ & 71 & $94.7 \%$ & \multirow{3}{*}{0.150} & \multirow{3}{*}{0.500} \\
\hline & Yes & & 3 & $4.0 \%$ & 4 & $5.3 \%$ & & \\
\hline & Total & & 75 & $100 \%$ & 75 & $\%$ & & \\
\hline
\end{tabular}

Table 2: Comparison between case and control groups regarding Haemoglobin, vitamin D levels and vitamin D status

\begin{tabular}{|c|c|c|c|c|c|c|}
\hline & \multicolumn{4}{|c|}{ Group } & \multirow{3}{*}{$\begin{array}{c}\text { Independent sample } \\
t \text { test }\end{array}$} & \multirow{3}{*}{ P-value } \\
\hline & \multicolumn{2}{|c|}{ Case group } & \multicolumn{2}{|c|}{ Control group } & & \\
\hline & Mean & $\pm \mathrm{SD}$ & Mean & $\pm \mathrm{SD}$ & & \\
\hline $\begin{array}{l}\text { Haemoglobin Level } \\
(\mathrm{gm} / \mathrm{dl})\end{array}$ & 10.02 & 1.79 & 11.01 & 1.36 & 1.6 & 0.085 \\
\hline Vitamin D Level (ng/ml) & 13.39 & 7.93 & 21.71 & 8.95 & 5.50 & 0.001 \\
\hline \multicolumn{7}{|c|}{ Group } \\
\hline \multirow[t]{2}{*}{ Vitamin D categories } & \multicolumn{2}{|c|}{ Case group } & \multicolumn{2}{|c|}{ Control group } & Chi square test & P-value \\
\hline & No. & $\%$ & No. & $\%$ & & \\
\hline Deficient & 60 & $80.0 \%$ & 29 & $38.7 \%$ & \multirow{4}{*}{$X^{2}=26.690$} & \multirow{4}{*}{0.001} \\
\hline Insufficient & 11 & $14.7 \%$ & 31 & $41.3 \%$ & & \\
\hline Sufficient & 4 & $5.3 \%$ & 15 & $20.0 \%$ & & \\
\hline Total & 75 & $100.0 \%$ & 75 & $100.0 \%$ & & \\
\hline
\end{tabular}

Table 3: Comparison between case and control groups regarding the duration of daily sunlight exposure

\begin{tabular}{|c|c|c|c|c|c|c|c|}
\hline \multirow{3}{*}{ Duration of Sun Exposure /day } & \multicolumn{4}{|c|}{ Groups } & \multirow{3}{*}{ P value } & \multirow{3}{*}{ Odds ratio } & \multirow{3}{*}{ Chi Square tes? } \\
\hline & \multicolumn{2}{|c|}{ Case group } & \multicolumn{2}{|c|}{ Control group } & & & \\
\hline & No & $\%$ & No & $\%$ & & & \\
\hline$<1 \mathrm{hr}$ & 31 & $41.3 \%$ & 10 & $13.3 \%$ & \multirow{4}{*}{$0.0001 *$} & 7.52 & \multirow{4}{*}{$X^{2}=25.445$} \\
\hline $1 \mathrm{hr}$ & 23 & $30.7 \%$ & 14 & $18.7 \%$ & & 3.98 & \\
\hline$>1 \mathrm{hr}$ & 21 & $28.0 \%$ & 51 & $68.0 \%$ & & & \\
\hline Total & 75 & $100.0 \%$ & 75 & $100.0 \%$ & & & \\
\hline
\end{tabular}


Table 4: Relation between daily sunlight exposure and vitamin D status in total study participants (both groups)

\begin{tabular}{|c|c|c|c|c|c|c|c|c|c|}
\hline & \multirow{3}{*}{ Sunlight Exposure / day } & \multicolumn{6}{|c|}{ Groups } & \multirow{2}{*}{\multicolumn{2}{|c|}{ Total }} \\
\hline & & \multicolumn{2}{|c|}{ Deficient } & \multicolumn{2}{|c|}{ Insufficient } & \multicolumn{2}{|c|}{ Sufficient } & & \\
\hline & & No & $\%$ & No & $\%$ & No & $\%$ & No & $\%$ \\
\hline$<1 \mathrm{hr}$ & & 41 & $46.1 \%$ & 0 & $0.0 \%$ & 0 & $0.0 \%$ & 41 & $27.3 \%$ \\
\hline $1 \mathrm{hr}$ & & 24 & $27.0 \%$ & 13 & $31.0 \%$ & 0 & $0.0 \%$ & 37 & $24.7 \%$ \\
\hline$>1 \mathrm{hr}$ & & 24 & $27.0 \%$ & 29 & $69.0 \%$ & 19 & $100.0 \%$ & 72 & $48.0 \%$ \\
\hline Total & & 89 & $100.0 \%$ & 42 & $100.0 \%$ & 19 & $100.0 \%$ & 150 & $100.0 \%$ \\
\hline & $\mathrm{X}^{2}$ & \multicolumn{8}{|c|}{56.434} \\
\hline & $\mathrm{P}$ & \multicolumn{8}{|c|}{$0.001 *$} \\
\hline
\end{tabular}

Table 5: Shows the relation between size of fibroid and Vitamin D level in the case group, also the different fibroid characteristics

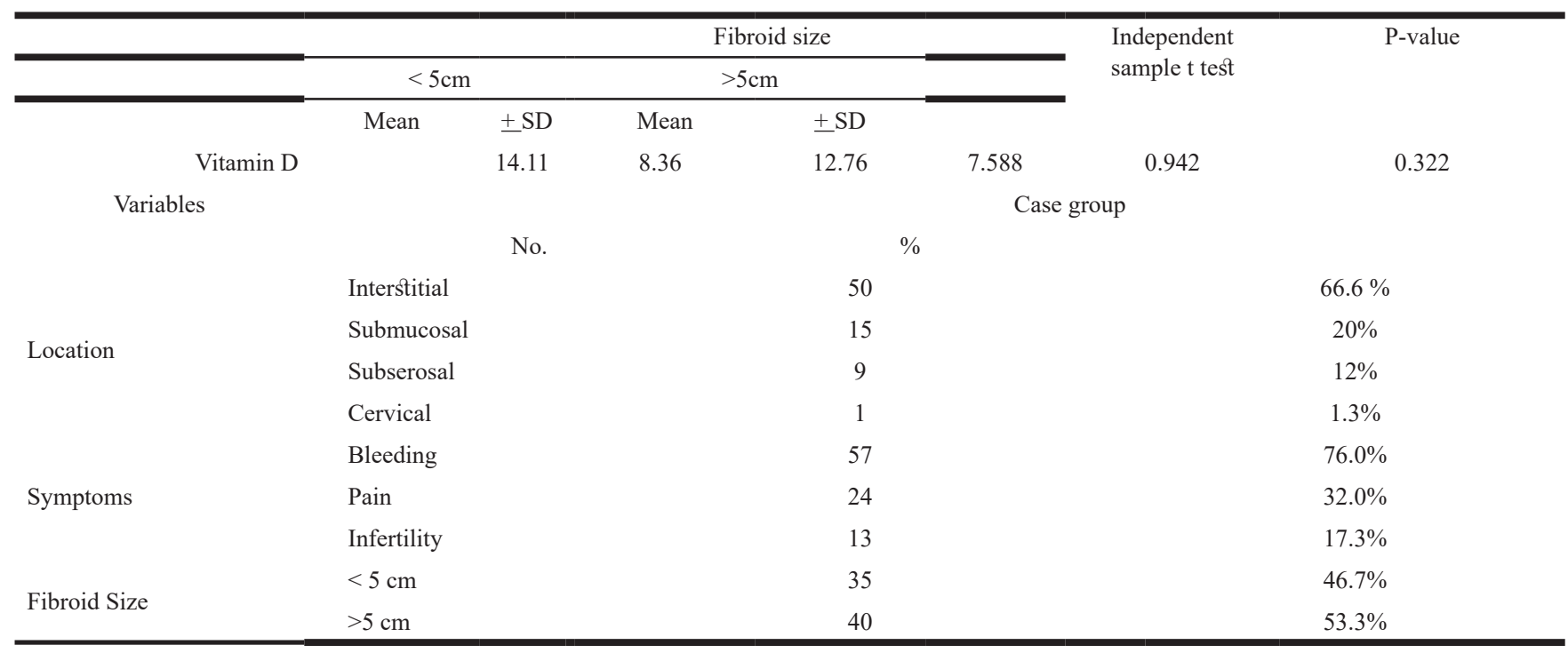

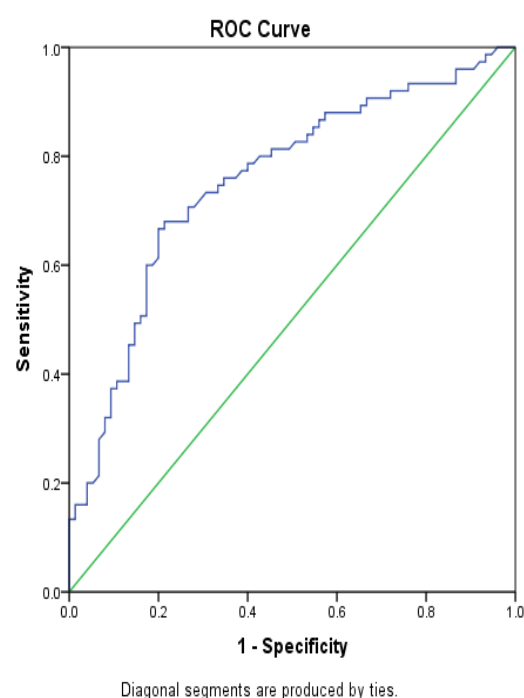

Fig. 1: ROC curve to predict the cut off value of vitamin D to predict uterine fibroid. 


\section{DISCUSSION}

The current study demonstrated a relationship between vitamin D level and uterine fibroid. The mean level of vitamin D was significantly lower in the case group in comparison to the control group $13.39 \pm 7.93 \mathrm{ng} / \mathrm{ml}$ and $21.71 \pm 8.95 \mathrm{ng} / \mathrm{ml}$, respectively denoting that low vitamin D level may serve as a risk factor for uterine fibroid development. According to our study, women with deficient vitamin D levels were 7.75 times more liable to develop uterine fibroid than women having vitamin D sufficient levels while the risk was 1.3 times higher in women having insufficient vitamin $\mathrm{D}$ levels ( $\mathrm{OR}=7.75$ vs 1.3 respectively) .

Many studies have shown similar results to the current study. Ajmani et al. ${ }^{[9]}$ (2018) conducted a similar casecontrol study and reported that the mean vitamin D level was $12.58 \pm 4.09 \mathrm{ng} / \mathrm{ml}$ vs $18.99 \pm 5.72 \mathrm{ng} / \mathrm{ml}$ for cases and control respectively $(p=0.001)$. The calculated odds ratio (OR) was $13.86 \mathrm{vs} 11.45 \mathrm{ng} / \mathrm{ml}$ for vitamin $\mathrm{D}$ deficient vs insufficient women respectively. The main difference between Ajmani et al from the current study was in the definition of vitamin D deficiency and sufficiency. They grouped women into 3 different groups according to World Health Organization recommendations: $25-\mathrm{OH}$ vitamin D deficiency $(<10 \mathrm{ng} / \mathrm{ml})$, insufficiency $(10-19.9 \mathrm{ng} / \mathrm{ml})$ and sufficiency $(>20 \mathrm{ng} / \mathrm{ml})$. On the other side, in our study, we used the definition of the Endocrine Society Practice Guidelines criteria of vitamin D status.

Kaplan et al ${ }^{[10]}$ also reported similar results in a casecontrol study conducted a case-control study on 124 premenopausal women. The mean vitamin D levels of the case group was significantly lower than the control group $(6.54 \pm 4.66 \mathrm{ng} / \mathrm{mLvs} .8 .18 \pm 5.16 \mathrm{ng} / \mathrm{mL}$, respectively; $p=0.009$ ). The reference rang e used to categorize the vitamin D level in both study groups was as the following equal or $>30 \mathrm{ng} / \mathrm{mL}=$ sufficient, 20-29.99 $\mathrm{ng} / \mathrm{mL}=$ deficiency, $<20 \mathrm{ng} / \mathrm{mL}=$ severe deficiency.

In our opinion, the lack of a standardized definition of vitamin D status between reporting studies is an upfronting problem when discussing results with different reference ranges for each category. In fact, this has led to discrepancies in reporting the prevalence of vitamin D deficiency in many studies and different populations such as Alagol et $a l^{[11]}$ who reported a wide range of vitamin D deficiency between $44-90 \%$ in a population based study.

In line with our results, 3 studies reported similar relation between serum vitamin D levels and uterine fibroid. Kumari et $a l^{[12]}$ conducted a case control study on 80 participants where the mean serum vitamin $\mathrm{D}(\mathrm{ng} / \mathrm{ml})$ was $15.48 \pm 4.96$ and $50.42 \pm 9.04$ $\mathrm{ng} / \mathrm{ml}$ for cases and control respectively with a highly statistical significant difference $(p=0.000)$. A peculiar observation in this study, was the remarkable high mean serum vitamin $\mathrm{D}$ value in the control group which was not reported by other studies. Paffoni et $a{ }^{[13]}$ evaluated 384 women prospectively and reported mean $25(\mathrm{OH})$ D levels were significantly lower in women with leiomyoma than controls $(18.0 \quad \pm 17.7 \quad \mathrm{ng} / \mathrm{mLvs} 20.8 \quad \pm 11.1 \quad \mathrm{ng} / \mathrm{mL})$ respectively. The calculated odds ratio for the presence of leiomyomas in women with serum levels of 25-hydroxyvitamin D3 deficiency was 2.4. Sabry et al. carried out a cross sectional observational study on 154 premenopausal women. The mean serum vitamin $D$ for cases and control were $19.7 \pm 11.8 \mathrm{ng} / \mathrm{ml}$ and $22.3 \pm 6.5 \mathrm{ng} / \mathrm{ml}$, respectively $(p=0.01)$. This seemed even more pronounced in blacks than whites (mean serum vitamin D levels were $14.2 \pm 5.2 \mathrm{ng} / \mathrm{dl}$ and $25.5 \pm 12.2 \mathrm{ng} / \mathrm{dl}$ for black and white women respectively.

In contrast to our results, Mitro et $a l^{[15]}$ performed a retrospective cross-sectional study on 3590 subjects and did not find correlation between 25(OH)D levels and uterine fibroid. Although the study recruited a large number of women with uterine leiomyoma, few distinct points from the current study are found. First, the retrospective nature of the study. Second, the study included both premenopausal and postmenopausal women. Third, the study depended on subjects' statement using a question if she had or ever been told to have uterine fibroid without objective diagnosis by ultrasound.

As regard the relation between sun exposure and fibroid in the current study, there was a highly statistical significant difference between cases and control groups regarding the duration of daily sunlight exposure $(P<0.0001)$. Women exposed to sunlight less than $1 \mathrm{hr} /$ day are 7.52 more liable to have uterine fibroid and women who are exposed to sunlight equal to $1 \mathrm{hr}$ /day are 3.98 more liable to have uterine fibroid.

Also, as regard sun exposure and vitamin $\mathrm{D}$ in the current study, 89 women $59.33 \%$ of all women enrolled in this study had deficient vitamin D level $\quad(<20 \quad \mathrm{ng} / \mathrm{ml}) \quad 42$ women $(28 \%)$ insufficient and 19 women $(12.66 \%)$ sufficient. Despite that our study was carried out during summer (from March to August, 2019) and the fact that Egypt is a country with one of the highest sunshine exposure hours, most women in the study were found with deficient vitamin D levels. This may be explained as most of our study participants were housewives with indoor lifestyle and no enough daily sunlight exposure also the women covering style in our country even with sufficient sun exposure more than 1 hour/day.

Similar results regarding sun exposure were reported by Baird et $a l^{[4]}$ who stated that despite $80 \%$ of women 
spent at least an hour per day outside in good weather, only $26 \%$ of them had sufficient circulating $25(\mathrm{OH})$ D $(>20 \mathrm{ng} / \mathrm{ml})$. Also, the mean $25(\mathrm{OH}) \mathrm{D}$ levels were substantially lower in blacks than whites $(10.4 \mathrm{ng} / \mathrm{ml} \pm 0.3$ and $20.7 \mathrm{ng} / \mathrm{ml} \pm 0.4$, respectively, $P<0.001$ ).

Kaplan et $a l^{[10]}$ in their study explained the high prevalence of vitamin D deficiency with the seasonal decrease in sun exposure and the covering clothing style. Their study was performed in winter-spring period and sunlight exposure was questioned with 'clothing style'. They reported that covering clothing style was significantly associated with vitamin D deficiency and vitamin D levels are affected by outdoor activities, sunlight exposure, clothing style and seasonal changes.

Regarding the secondary outcome for the current study to investigate the correlation between serum vitamin D level and the size of uterine fibroid, the mean serum vitamin D level in patients with fibroid size less than 5 $\mathrm{cm}$ was $14.11 \mathrm{ng} / \mathrm{ml}$, while women with fibroid size more than $5 \mathrm{~cm}$ had mean serum vitamin D level of $12.76 \mathrm{ng} /$ $\mathrm{ml}$ with $(P=0.457)$ with no statistical significant difference between the size of fibroid and vitamin $\mathrm{D}$ level.

Matched with our results, Kaplan et al. ${ }^{[10]}$ stated that the mean vitamin D levels were statistically similar between patients with leiomyoma with a diameter $<40 \mathrm{~mm}$ and $>40 \mathrm{~mm}(6.37 \pm 4.59 \mathrm{ng} / \mathrm{mLvs} 6.66 \pm 4.78 \mathrm{ng} / \mathrm{mL}, \mathrm{p}=.881)$; patients with one or multiple leiomyoma $(6.67 \pm 5.06 \mathrm{ng} / \mathrm{mL}$ vs. $6.37 \pm 4.22 \mathrm{ng} / \mathrm{mL}, \mathrm{p}=.965)$; patients with leiomyoma number $<3$ or $>3(6.88 \pm 4.80 \mathrm{ng} / \mathrm{mL}$ vs. $5.07 \pm 3.83 \mathrm{ng} /$ $\mathrm{mL} ; p=.061)$.

In contrast to our results, Sabry et $a l^{[14]}$ reported a statistically significant inverse correlation $(\mathrm{r}=-0.31$; $P=0.002)$ between serum 25-(OH) Vit D levels and total volume of uterine fibroids within the case cohort. This means that for participants with uterine fibroids, the lower the serum vitamin D levels, the larger the total fibroid volume, and vice versa.

\section{CONCLUSION}

The current study showed a significant association between vitamin $\mathrm{D}_{3}$ deficiency in reproductive age women and the occurence of uterine fibroid, the mean vitamin $\mathrm{D}_{3}$ level in the case group was $13.39 \pm 7.93 \mathrm{ng} / \mathrm{ml}$ and in the control group was $21.71 \pm 8.95 \mathrm{ng} / \mathrm{ml}$. There is no correlation between vitamin $\mathrm{D}_{3}$ level and the size of uterine fibroid. Vitamin $\mathrm{D}_{3}$ deficiency is widely spread among the study population with $60 \%$ prevalence and vitamin $\mathrm{D}_{3}$ insufficient with $28 \%$ prevalence among study participants.

\section{CONFLICT OF INTERESTS}

There are no conflict of interests

\section{REFERENCES}

1. Sarais V, Cermisoni GC, Schimberni M, Alteri A, Papaleo E, Somigliana E, et al. Human chorionic gonadotrophin as a possible mediator of leiomyoma growth during pregnancy: molecular mechanisms. Int J Mol Sci 2017; 18: 2014.

2. Ciebiera M, Włodarczyk M, Wrzosek $M$, Słabuszewska-Jóźwiak A, Nowicka G, Jakiel G. Ulipristal acetate decreases transforming growth factor beta3 serum and tumor tissue concentrations in patients with uterine fibroids. Fertil Steril 2018; 109:501-7.

3. Islam MS, Akhtar MM, Segars JH, Castellucci M, Ciarmela P. Molecular targets of dietary phytochemicals for possible prevention and therapy of uterine fibroids: Focus on fibrosis. Crit Rev Food Sci Nutr 2017; 57:3583-600.

4. Baird DD, Dunson DB, Hill MC, Cousins D, Schectman JM. High cumulative incidence of uterine leiomyoma in black and white women: ultrasound evidence.AmJ Obstet Gynecol. 2003;188:100-107.

5. Protic O, Islam MS, Greco S, Giannubilo SR, Lamanna $\mathrm{P}$, Petraglia $\mathrm{F}$, et al. Activin $\mathrm{A}$ in inflammation, tissue repair, and fibrosis: Possible role as inflammatory and fibrotic mediator of uterine fibroid:development and growth. Semin Reprod Med 2017; 35:499-509.

6. Sharan C, Halder SK, Thota C, Jaleel T, Nair S, Al-Hendy A. Vitamin D inhibits proliferation of human uterine leiomyoma cells via catechol-Omethyltransferase. Fertil Steril 2011; 95:247-53.

7. Blauer M, Rovio PH, Ylikomi T, Heinonen PK. Vitamin D inhibits myometrial and leiomyoma cell proliferation in vitro. Fertil. Steril. 2009; 91: 1919-1925.

8. Pludowski P, Holick MF, Grant WB, Konstantynowicz J, Mascarenhas MR, Haq A, Povoroznyuk V, Balatska $\mathrm{N}$, Barbosa AP, Karonova $\mathrm{T}$, et al. Vitamin D supplementation guidelines. J. Steroid Biochem. Mol. Biol. 2018; 175: 125-135.

9. Ajmani SN, Sarbhai V, Singh S, Ajmani AK, Leela P. To establish the association of vitamin D levels with leiomyoma and its role as a risk factor for development of leiomyoma uterus. Indian Obstetrics and Gynaecology. 2018; 8(4). 
10. Kaplan ZAO, Taşçi Y, Topçu HO \& Erkaya S. 25-Hydroxy vitamin $D$ levels in premenopausal Turkish women with uterine leiomyoma. Gynecological Endocrinology 2017.

11. Alagöl F, Shihadeh Y, Boztepe H, Tanakol R, Yarman S, Azizlerli H, Sandalci O. Sunlight exposure and vitamin D deficiency in Turkish women. J Endocrinol Invest. 2000;23(3):173-177.

12. Kumari S, Babu D, Singh S. Association Of Vitamin D, Calcium And Phosphate With Uterine Fibroid In Premenopausal Women Of Coastal Odisha. International Journal Of Scientific Research. $2019 ; 8(2)$
13. Paffoni A, Somigliana E, Vigano P, Benaglia L, Cardellicchio L, Pagliardini L, Papaleo E, Candiani M and Fedele L. Vitamin D status in women with uterine leiomyomas. J Clin Endocrinol Metab, August 2013; 98(8): 1374-1378.

14. Sabry M, Halder SK, Allah AS, Roshdy E, Rajaratnam V, Al-Hendy A. Serum vitamin D3 level inversely correlates with uterine fibroid volume in different ethnic groups: A cross-sectional observational study. Int. J. Women's Health 2013; 5: 93-100.

15. Mitro D , Zotaa A. Vitamin D and uterine leiomyoma among a sample of US women: Findings from NHANES, 2001-2006. J.Reprod Toxicol 2015; 57: 81-86. 